\title{
Four Olethreutinae new to the Italian fauna from Tuscan-Romagnol Appennines (Lepidoptera, Tortricidae)
}

\author{
P. Trematerra, M. Colacci \\ Department of Agriculture, Environmental and Food Sciences, University of Molise, Campobasso, Italy
}

\begin{abstract}
Lobesia andereggiana (Herrich-Schäffer), Ancylis rhenana (MüllerRutz), Eucosma agnatana (Christoph) and Lathronympha balearici Diakonoff (Lepidoptera, Olethreutinae) are reported for first time from the Italian fauna. The four species of Lepidoptera Tortricidae were collected from the Tuscan-Romagnol Appennines in the upper Acerreta Valley.
\end{abstract}

\section{Introduction}

Our report focuses on four Lepidoptera Tortricidae species from the Olethreutinae subfamily that are new to the Italian fauna: Lobesia andereggiana (Herrich-Schäffer, 1851), Ancylis rhenana Müller-Rutz, 1920, Eucosma agnatana (Christoph, 1872) and Lathronympha balearici Diakonoff, 1972. The four species were captured by Adelmo Usvelli, an Italian naturalist and entomologist, from around the Badia Valley, in the province of Florence in the upper Acerreta Valley. The territory, located in the northern side of the Apennines, is administratively assigned to the province of Florence but biogeographically falls in Romagna (Zangheri P., 1966-70) (Figure 1).

Correspondence: Pasquale Trematerra, Dipartimento Agricoltura, Ambiente e Alimenti - Università degli Studi del Molise, via De Sanctis 1, 86100 Campobasso, Italy.

Tel.: +39.0874.404655 - Fax: +39.0874 .404855 .

E-mail: trema@unimol.it

Key words: Lepidoptera; Tortricidae; Olethreutinae; new records; Italy.

Contributions: the authors contributed equally.

Conflict of interests: the authors declare no potential conflict of interests.

Received for publication: 29 February 2016.

Revision received: 4 October 2016.

Accepted for publication: 4 October 2016.

(C) Copyright P. Trematerra e M. Colacci, 2016

Licensee PAGEPress, Italy

Journal of Entomological and Acarological Research 2016; $48: 5856$

doi:10.4081/jear.2016.5856

This article is distributed under the terms of the Creative Commons Attribution Noncommercial License (by-nc 4.0) which permits any noncommercial use, distribution, and reproduction in any medium, provided the original author(s) and source are credited.
In order to list the different species, we follow the arrangement adopted by Razowski (2003) and Brown (2005); biology, hosts and distribution are from Trematerra (2003) above all, with some modifications suggested by Aarvik (2013).

\section{Lobesia andereggiana (Herrich-Schäffer, 1851)}

Olethreutinae, tribe Olethreutini

MATERIAL EXAMINED. 1 male, Romagna Marradi FI, Badia Valle, m. 430, L. Usvelli, 1.VII.91; 1 male, idem, 5.VII.99.

DIAGNOSIS. Externally Lobesia andereggiana is similar to L. virulenta mieana (Falck \& Karsholt, 1998) (Figure 2); however, the male genitalia differ. In $L$. andereggiana, male genitalia present sacculus concave in middle ventrally, then strongly convex to form a finger like a spiny process; incision before angle of sacculus distinct, this last with a group of longer spines anteriorly (Figure 3).

DISTRIBUTION. L. andereggiana is a Western Palaearctic specie known in Central and Southern Europe (France, Switzerland, Austria, Slovenia, Croatia, Slovakia, Romania), the Taurus Mountains and the Asia Minor.

BIOLOGY. An univoltine species; moths are collected in June-July. In Crimea, it flies in early May-June (Budashkin, 1993). Larva feeds in the leaves, flowers and fruits of the Dianthus carthusianorum L.

Ancylis rhenana Müller-Rutz, 1920

Olethreutinae, tribe Enarmoniini

MATERIAL EXAMINED. 1 male, Romagna Marradi FI, M. Bruno, m.

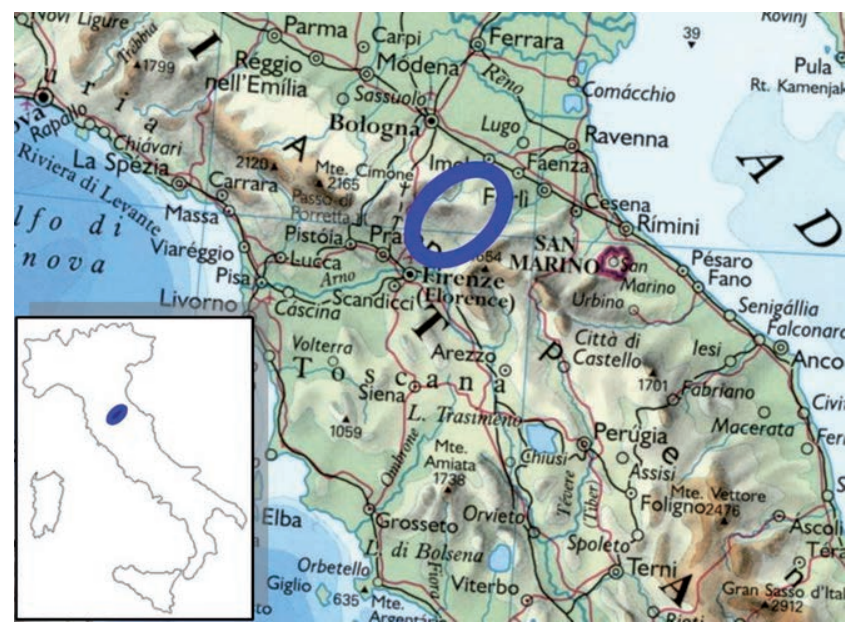

Figure 1. Schematic representation of the study area. 
700, L. Usvelli, 26.VII.00; 1 female, Romagna Marradi FI, Badia Valle, m. 430, L. Usvelli, 28.VII.00; 1 female, idem, 21.VIII.00; 1 female, idem, 24.VIII.00.

DIAGNOSIS. Ancylis rhenana is similar to A. badiana (Denis \& Schiffermüller, 1775) and A. paludana (Barrett, 1871) (Figure 4). Compared to the $A$. paludana, the male genitalia of the $A$. rhenana cucullus are shorter, ventro-anteriorly more expanding, the termination of the sacculus sharper, and the female anteostial sterigma and colliculum are shorter (Figure 5).

DISTRIBUTION. Europe (Finland, Estonia, Latvia, Germany, Switzerland, Austria).

BIOLOGY. Adults collected in April-May and in July; in our case $A$. rhenana was also captured in July and August. Host unknown; according to Razowski (2003) Ancylis larvae spin leaves from deciduous trees, often from the Betulaceae and Salicaceae, or they feed on fruits.

\section{Eucosma agnatana (Christoph, 1872)}

\section{Olethreutinae, tribe Eucosmini}

MATERIAL EXAMINED. 1 female, ROMAGNA: RA, M. Mauro, L.G. Fiumi, 6.9.88; 1 male, Romagna Marradi FI, Badia Valle, m. 430, L. Usvelli, 24.VIII.00.

DIAGNOSIS. The Eucosma agnatana adult is similar to the E. fervidana (Zeller, 1847) (Figure 6). E. agnatana is reported by Razowski (2003) among E. albidulana (Herrich-Schäffer, 1851) and E. apocrypha (Falkovitsh, 1964). In male genitalia of $E$. agnatana the caudal angle of the sacculus is rather weakly rounded; the neck of the valve is moderately broad; the ventral incision is distinct; the ventral lobe of the cucullus is short; the caudal edge of cucullus convex medially (Figure 7). In female genitalia the postostial part of the sterigma is rather large; cingulum median; the signa pair are large and rather equal (Figure 8).

DISTRIBUTION. Southern part of East Europe, Central and Southern Europe, Russia, Asia Minor, Kazakhstan, Kirgizia, Mongolia.

BIOLOGY. Moths collected in August-September. Larvae recorded in Artemisia fragrans Willd., A. nutants Willd. and A. monogyna Waldst. \& Kit. (Razowski, 2003).

\section{Lathronympha balearici Diakonoff, 1972}

\section{Olethreutinae, tribe Grapholitini}

MATERIAL EXAMINED. 1 female, Romagna Marradi FI, Badia Valle, m. 430, L. Usvelli, 24.VII.91; 1 female, idem, 30.VII.91; 1 male, idem, 3.VIII.91; 1 male, idem, 23.VIII.91; 1 female, idem, 20.VIII.92; 1 male, idem, 16.VI.94; 1 female, idem, 8.VI.96; 2 males, idem, m. 500, 28.VII.97; 1 female, Romagna Marradi FI, Ponte Valle, m. 500, L. Usvelli, 29.VII.97; 1 male, idem, 08.VI.1999, A. Usvelli legit; 1 male, idem, 26.VII.99; 1 female, idem, 05.VIII.1999, A. Usvelli legit; 1 male, idem, 31.V.2000, idem; 1 male, idem, 03.VII.2000, idem; 2 males, idem, 26.VII.2000, idem; 1 male, idem, 05.VI.2003, idem; 1 male, idem, 23.VII.2003, idem.

DISTRIBUTION. Balearic Islands (Mallorca) (Diakonoff, 1982); in the list of Fauna Europaea, a record in Estonia (Aarvik, 2013) was also reported.

BIOLOGY. Moths collected in May and October, in our case adults of L. balearici, were also found in June-July and August. Larva beaten from Hypericum balearicum L. (Diakonoff, 1982). According to the distribution of the species food plants need more information.

DIAGNOSIS. Lathronympha balearici is similar to $L$. sardinica Trematerra, 1995 (Figure 9). L. balearici can be identified in male genitalia by slender, tapering and terminally curved aedeagus (Figure 10); in female genitalia sterigma is short, with an expanding distal part, and rounded proximally (Figure 11).

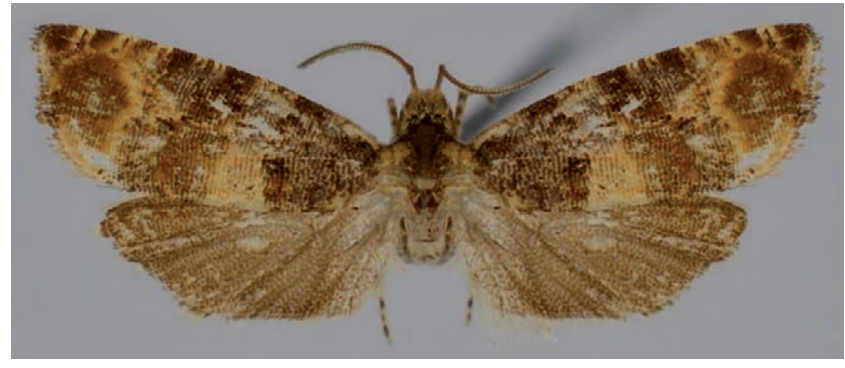

Figure 2. Lobesia andereggiana (Herrich-Schäffer): adult.

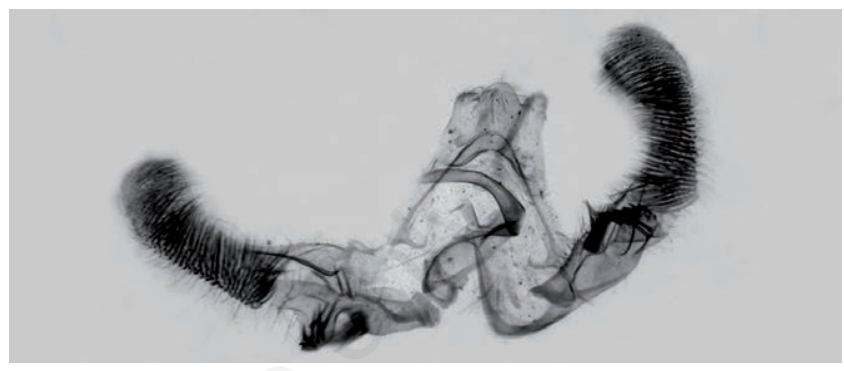

Figure 3. Lobesia andereggiana (Herrich-Schäffer): male genitalia.

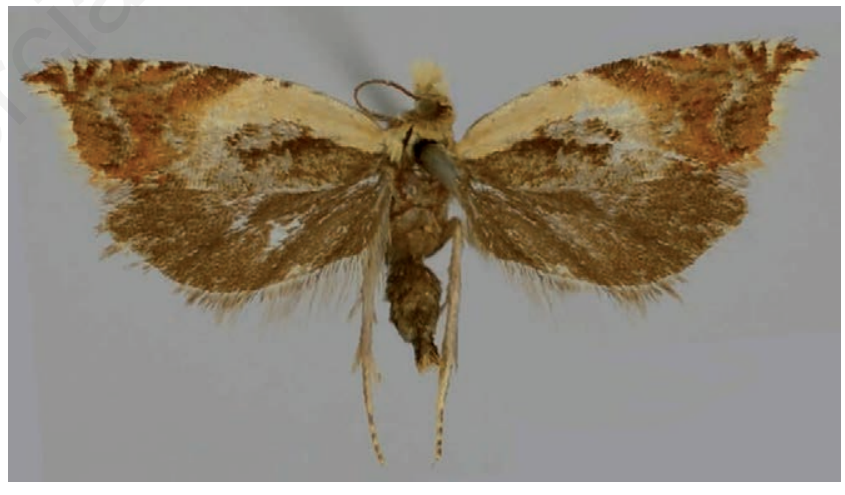

Figure 4. Ancylis rhenana Müller-Rutz: adult.

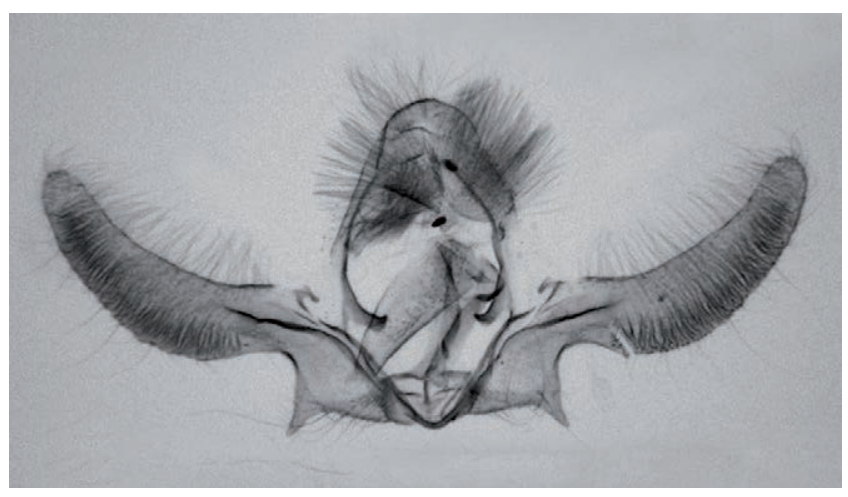

Figure 5. Ancylis rhenana Müller-Rutz: male genitalia. 


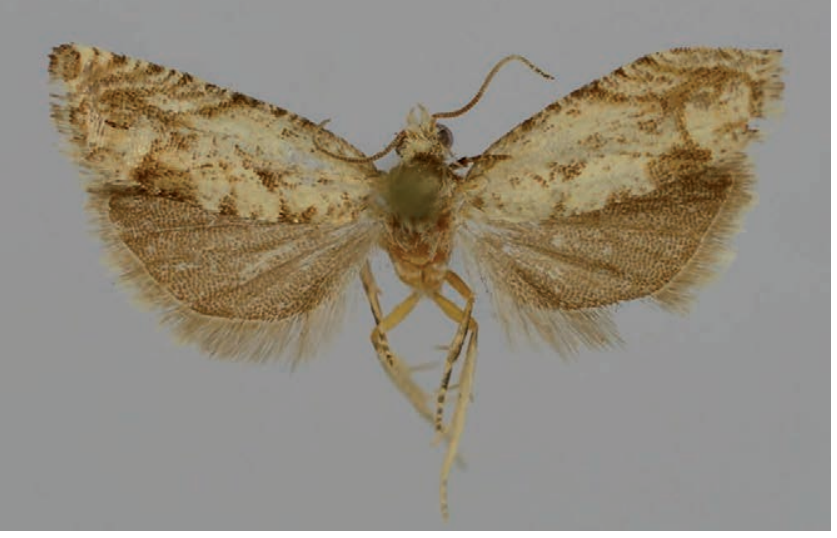

Figure 6. Eucosma agnatana (Christoph): adult.

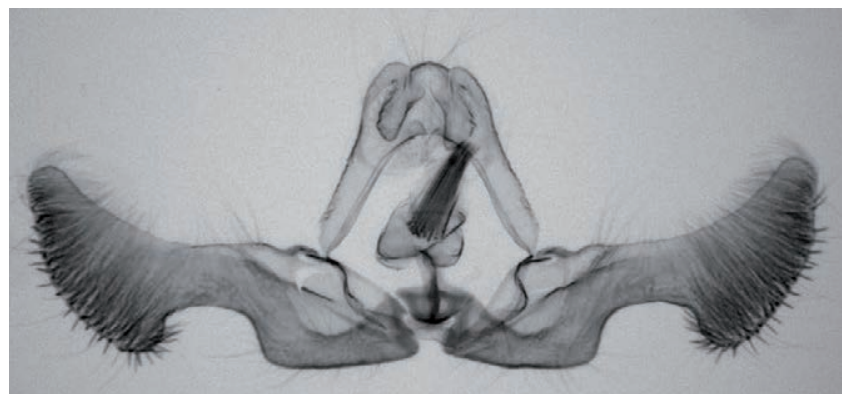

Figure 7. Eucosma agnatana (Christoph): male genitalia.

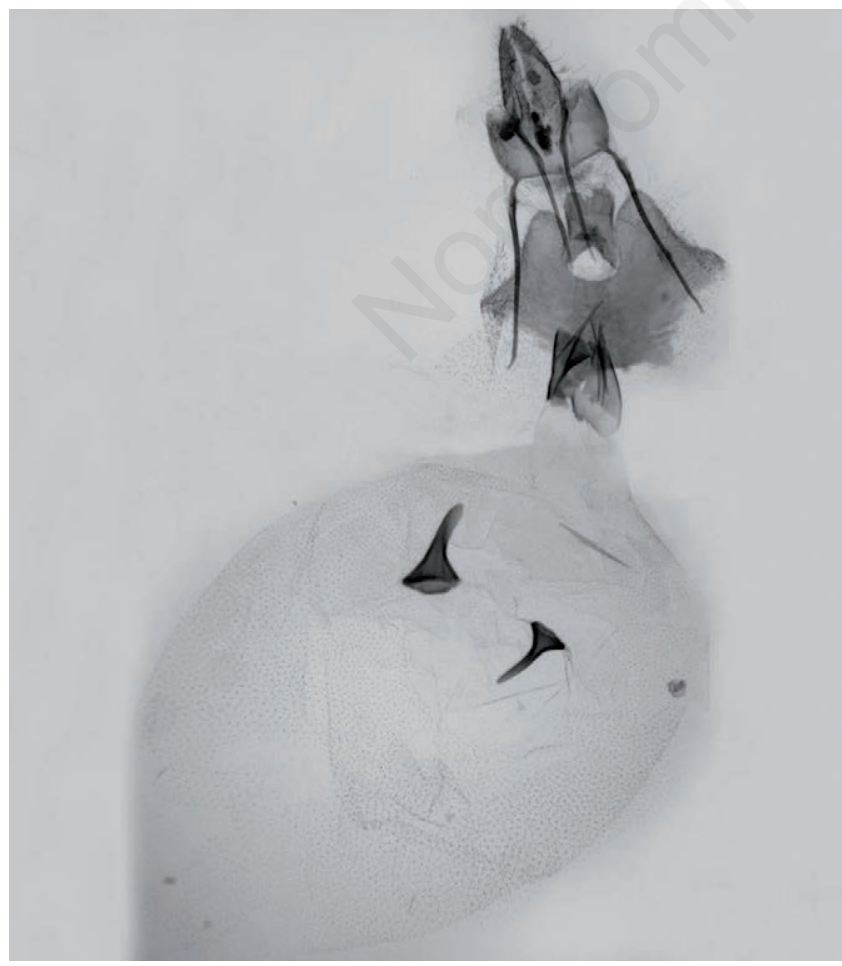

Figure 8. Eucosma agnatana (Christoph): female genitalia.

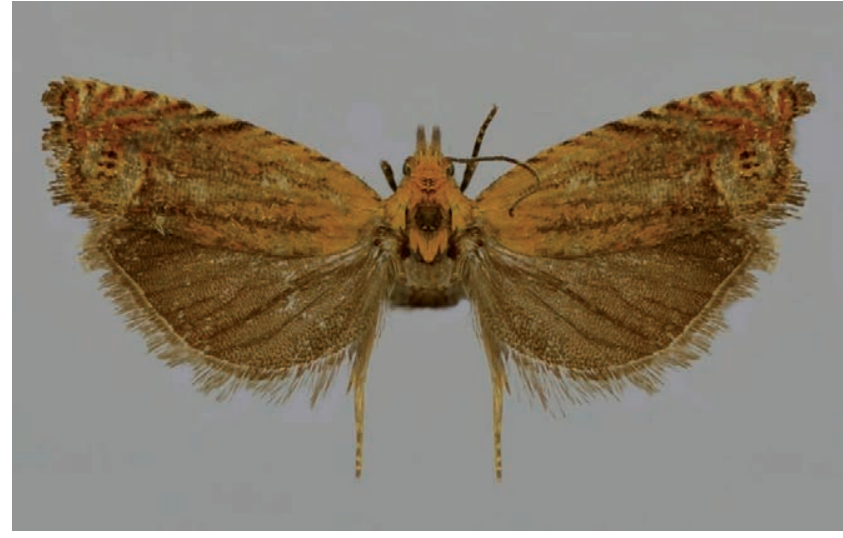

Figure 9. Lathronympha balearici Diakonoff: adult.

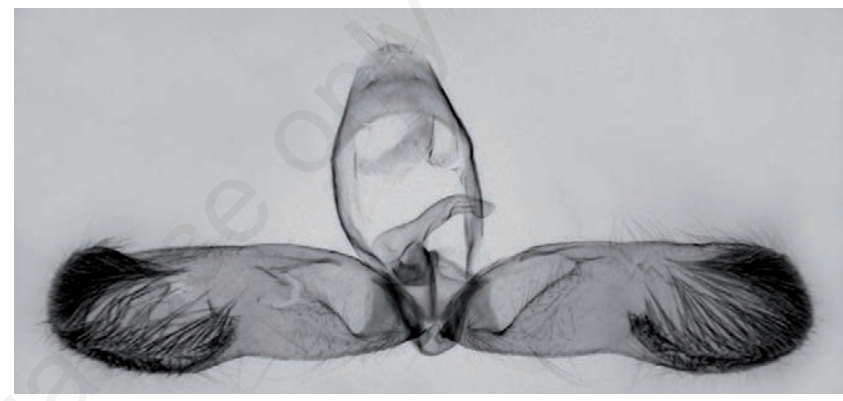

Figure 10. Lathronympha balearici Diakonoff: male genitalia.

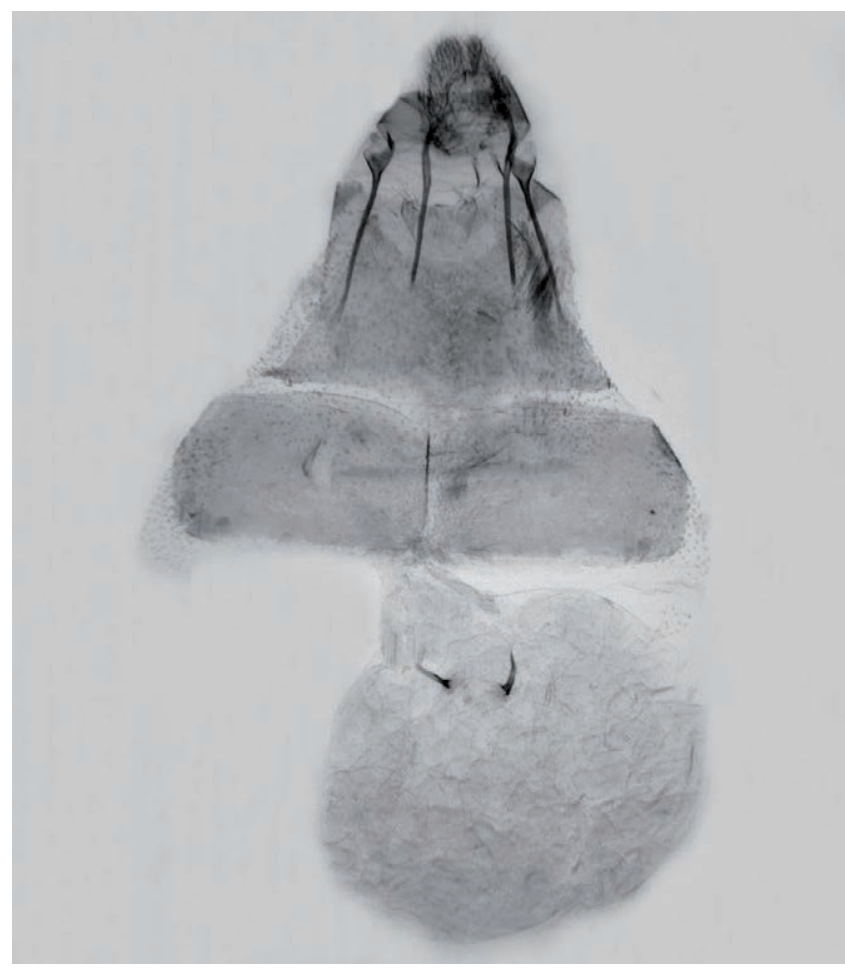

Figure 11. Lathronympha balearici Diakonoff: female genitalia. 


\section{References}

AARVIK L.E., 2013 - Fauna Europaea: Tortricidae. In: KARSHOLT 0. \& NIEUKERKEN E.J. VAN, Fauna Europaea: Lepidoptera, Moths. Fauna Europaea version 2.6.2, http://www.faunaeur.org.

BROWN J., 2005 - World catalogue of insects. Vol. 5. Tortricidae (Lepidoptera). - Apollo Books, Stenstrup: 741 pp.

BUDASHKIN J.I., 1993 - New materials on taxonomy and biology of Palaearctic leafrollers (Lepidoptera, Tortricidae). - Vestnik Zool., 2: 45-53.

DIAKONOFF A., 1972 - Description of a new species of Lasperyresiini

from Balearic Islands (Lepidoptera, Tortricidae). - Entomolog. Ber., 32: 65-68.

RAZOWSKI J., 2003 - Tortricidae of Europe. Vol. 2. Olethreutinae. Frantisek Slamka, Bratislava: $301 \mathrm{pp}$.

TREMATERRA P., 1995 - Description of a new species of Laspeyresiini, Lathronympha sardinica sp.n. (Lepidoptera Tortricidae). - Boll. Zool. agr. Bachic., Ser. II, 27: 185-190.

TREMATERRA P., 2003 - Catalogo dei Lepidoptera Tortricidae della fauna italiana: geonemia, distribuzione in Italia, note biologiche, identificazione. - Boll. Zool. agr. Bachic., Ser. II, 35: 1-270.

ZANGHERI P., 1966-70 - Repertorio sistematico e topografico della Flora e della Fauna, vivente e fossile, della Romagna. - Memorie (f. s.) N.1., Museo civ. St. nat. Verona, (5 vols): 1-1963. 